\title{
The Fermenting Bacterium Malonomonas rubra is Phylogenetically Related to Sulfur-Reducing Bacteria and Contains a c-Type Cytochrome similar to those of Sulfur and Sulfate Reducers
}

\author{
Sylvie Kolb ${ }^{1}$, Sabine Seeliger ${ }^{1}$, Nina Springer², Wolfgang Ludwig ${ }^{2}$ and Bernhard Schink ${ }^{1 *}$ \\ ${ }^{1}$ Fakultät für Biologie, Universität Konstanz, Germany \\ ${ }^{2}$ Lehrstuhl für Mikrobiologie der Technischen Universität München, Germany
}

\begin{abstract}
Summary
Malonomonas rubra is a microaerotolerant fermenting bacterium which can maintain its energy metabolism for growth by decarboxylation of malonate to acetate. $16 \mathrm{~S} r \mathrm{RNA}$ sequence analysis revealed that $M$. rubra is closely related to the cluster of mesophilic sulfur-reducing bacteria within the delta subclass of the Proteobacteria, with the fermenting bacterium Pelobacter acidigallici and the sulfur reducers Desulfuromusa kysingii, D. bakii and D. succinoxidans as closest relatives. The cells contain high amounts (up to $12 \%$ of the total cell protein content) of a $c$-type cytochrome which is present mainly $(>60 \%)$ in the cytoplasm and to minor parts in the periplasm $(>20 \%)$ and associated with the membrane fraction $(>10 \%)$, independent of the growth substrate. This cytochrome is a tetraheme cytochrome of $13,700 \mathrm{Da}$ molecular mass with a midpoint redox potential of $-0.210 \mathrm{~V}$. M. rubra does not reduce sulfur or ferric iron compounds. Since this cytochrome appears not to be involved in the energy metabolism it is concluded that it is a remnant of sulfur-reducing ancestors of this bacterium, without a conceivable physiological function in its present energy metabolism.
\end{abstract}

Key words: cytochrome $c$ - sulfur-reducers - sulfat-reducers - decarboxylation - malonate

\section{Introduction}

Malonomonas rubra was isolated as a fermenting bacterium able to grow by decarboxylation of malonate to acetate (DEHNING and SCHINK, 1989). It can also ferment malate or fumarate to succinate and $\mathrm{CO}_{2}$. The red pigmentation of the cells was conspicuous from the beginning, staining colonies in deep agar culture intensely red. Spectral analysis revealed that this pigmentation was due to a high content of cytochrome $c$ in the cells, however, the metabolism of this bacterium gave no clue to a possible function of this cytochrome in electron transfer reactions.

The present study aimed at a characterization and elucidation of possible functions of this cytochrome in the energy metabolism of M. rubra. Moreover, comparative $16 \mathrm{~S}$ rRNA sequence analysis was performed in order to obtain possible hints for phylogenetic relationships to bacteria with other metabolic capacities.

\section{Materials and Methods}

Strains source, media, and growth conditions: Malonomonas rubra strain GraMal1, DSM 5091, was from our own culture collection, and was checked for purity at regular intervals by microscopy after growth in mineral medium with malonate as sole substrate, or in complex medium (Difco AC medium; diluted 1:10). M. rubra was grown in bicarbonate/ $\mathrm{CO}_{2}$-buffered, sulfide-reduced mineral medium adapted for marine bacteria (WIDDEL and PFENNIG, 1981), containing 7-vitamin solution (WIDDEL and PFENNIG, 1981), selenite-tungstate solution (TSCHECH and PFENNIG, 1984) and the trace element solution SL10 (WIDDEL et al., 1983). The final pH of the medium was adjusted to 7.2-7.4. The growth temperature was $28{ }^{\circ} \mathrm{C}$. Substrates were added from sterile, neutralized stock solutions. Mass cultures were grown in 51 carboys with $20 \mathrm{mM}$ malonate as substrate. Cells were harvested by centrifugation at 10,000 $\mathrm{x}$ $\mathrm{g}$ for $25 \mathrm{~min}$.

Phylogenetic analysis: In vitro amplification and direct sequencing of $16 \mathrm{~S}$ rRNA encoding DNA fragments was done as described earlier (SPRINGER et al., 1992). The sequence data 
have been deposited at the EBI database under accession number 17712. The new $16 S$ rRNA sequence was fitted into an alignment of about 10,000 homologous full and partial primary structures available in public databases (LUDwIG, 1995) using the respective automated tools of the $A R B$ software package (LUDWIG and STRUNK, 1996). Distance matrix, maximum parsimony and maximum likelihood methods were applied for tree reconstruction as implemented in the ARB software package. Different data sets varying with respect to included outgroup reference organisms (sequences) as well as alignment positions were analyzed.

Localization experiments: Cells were harvested at the end of exponential growth by 25 min centrifugation at $10,000 \times \mathrm{g}$, washed one and resuspended in $50 \mathrm{mM}$ Tris- $\mathrm{HCl}, \mathrm{pH} 7.0 .20 \%$ $(\mathrm{w} / \mathrm{v})$ sucrose, $2 \mathrm{mM}$ EDTA and $1 \mathrm{mg}$ lysozyme per $\mathrm{ml}(21,500$ $\mathrm{U} \times \mathrm{mg}$ protein ${ }^{-1}$ ) were added, and the suspension was incubated for at least 1 hour at $28^{\circ} \mathrm{C}$. Spheroplast formation was followed microscopically. Spheroplasts were removed by $30 \mathrm{~min}$ centrifugation at $5,000 \times \mathrm{g}$, and the supernatant was cleared of cell debris afterwards by $30 \mathrm{~min}$ centrifugation at $45,000 \times \mathrm{g}$ to give the periplasmic fraction. Cytoplasm and membrane fractions were obtained from spheroplasts by centrifugation at $120,000 \times g$ after sonication. Malate dehydrogenase activity was measured as a tracer of the cytoplasmic fraction in the periplasmic fraction and culture supernatant measuring NADH oxidation with oxaloacetate (STAMS et al., 1984). Pyridine hemochromes were extracted after published procedures (WESTON and KNOWLES, 1973).

Purification of cytochrome $c$ : Purification started with the periplasmic fraction which was applied to a $0.6 \times 5 \mathrm{~cm}$ cation exchanger column (Mono S, prepacked, Pharmacia, Sweden) preequilibrated with $25 \mathrm{mM}$ sodium phosphate buffer, $\mathrm{pH}$ 6.3, as eluent. In a linear gradient up to $1 \mathrm{M} \mathrm{NaCl}$, the cytochrome eluted at $270-300 \mathrm{mM} \mathrm{NaCl}$ concentration. The fraction containing cytochrome $c$ (detected by the absorption spectrum of its reduced form) was loaded on a gel filtration column $(1.25 \times 30 \mathrm{~cm}$, Superose 12 prepacked, Pharmacia, Sweden) run with $0.15 \mathrm{M}$ ammonium acetate buffer, $\mathrm{pH}$ 6.3. The fraction containing the $\mathrm{cy}$ tochrome was concentrated by lyophilization since the cytochrome tended to attach to ultrafiltration membranes. The concentrate in a $1.7 \mathrm{M}$ ammonium acetate concentration was loaded on a hydrophobic interaction column $(1.25 \times 10.5 \mathrm{~cm}$, Phenyl Superose prepacked, Pharmacia, Sweden). The cytochrome eluted with $1.7 \mathrm{M}$ ammonium acetate, whereas the remaining contaminating proteins were retained and eluted at lower ionic strength. The cytochrome fraction was lyophilized, redissolved in two steps with ten volumes of distilled water each, and lyophilized again.

Characterization of cytochrome $c$ : For SDS gel electrophoresis the method of LAEMMLI (1970) was applied with $12 \%$ or $14 \%$ polyacrylamide for resolving gels and $4 \%$ for stacking gels. Samples were diluted in sample buffer containing $60 \mathrm{mM}$ Tris/ $\mathrm{HCl}, 2 \%(\mathrm{w} / \mathrm{v})$ SDS, $10 \%(\mathrm{w} / \mathrm{v})$ glycerol, $0.025 \%(\mathrm{w} / \mathrm{v})$ bromophenol blue, and no mercaptoethanol. Electrophoresis was carried out ion a dual slab cell (Mini-Protean II, Bio-Rad, USA) with Tris/Glycin/SDS-buffer ( $25 \mathrm{mM}, 250 \mathrm{mM}, 0.1 \%$ $\mathrm{w} / \mathrm{v}$, respectively), starting at $30 \mathrm{~mA}$ until samples entered the resolving gel, and separating at $40 \mathrm{~mA}$. Heme staining in SDS gels was performed as described earlier (THOMAs et al., 1976) with modifications by GOODHEW et al. (1986).

The molecular mass of the purified cytochrome $c$ was estimated by gel filtration chromatography on a Hi-Load Superdex 75 preparation-grade column (Pharmacia BioSystems, Freiburg) equilibrated with $50 \mathrm{mM}$ potassium phosphate buffer, $\mathrm{pH} 7.2$, containing $0.5 \mathrm{M} \mathrm{NaCl}$. The void volume was determined with dextran blue ( $1 \mathrm{mg}$ per $\mathrm{ml}$ ), and the column was calibrated with the low-molecular-weight calibration kit (Pharmacia, Freiburg).
The midpoint redox potential was determined by titration with $100 \mu \mathrm{M}$ benzyl viologen $\left(\mathrm{E}^{\circ}=-360 \mathrm{mV}\right)$, flavin adenin dinucleotide $\left(E^{\circ}=-219 \mathrm{mV}\right)$, flavin mononucleotide $\left(\mathrm{E}^{\circ}=\right.$ $-190 \mathrm{mV}$ ) and $100 \mu \mathrm{M}$ indigodisulfonate $\left(E^{\circ}=-125 \mathrm{mV}\right)$ as redox indicators, dithionite as reductant, and air as oxidant. Absorptions of dyes and cytochrome were recorded with a double-beam UV/VIS spectrophotometer (Uvikon 860, Kontron, Switzerland).

For determination of total iron content, cytochrome solutions were dissolved in $0.1 \mathrm{M} \mathrm{NaOH}$, and the iron concentration was determined with an atomic absorption spectrophotometer (303B, Perkin Elmer, Norwalk, CT, USA) at $284.3 \mathrm{~nm}$.

Analytical methods: Cytochrome $c$ was quantified taking redox difference absorption spectra of dithionite-reduced minus air- or hydrogen peroxide-oxidized preparations. The specific absorption coefficient was determined with the purified cytochrome, and applied for quantification in cell subfractions. Spectra were recorded with double beam UV/VIS spectrophotometers (Uvikon 860 or 930 , Kontron, Switzerland) at room temperature. Glass and quartz cuvettes used had $1 \mathrm{ml}$ total volume, $1 \mathrm{~cm}$ light path, and were sealed with rubber stoppers and gassed with nitrogen for anoxic measurements. Peak heights were measured relative to a baseline drawn between the troughs at 530-535 and 565-570 nm. Protein was quantified according to BRADFORD (1976).

Chemicals: All chemicals were of analytical or reagent grade quality and were obtained from Biomol (Ilvesheim, Germany), Boehringer (Mannheim, Germany), Eastman Kodak (Rochester, NY, USA), Fluka (Neu-Ulm, Germany), Merck (Darmstadt, Germany), Pharmacia (Freiburg, Germany), Serva (Heidelberg, Germany), and Sigma (Deisenhofen, Germany). Gases were purchased from Messer-Griesheim (Darmstadt, Germany), and Sauerstoffwerke Friedrichshafen (Friedrichshafen, Germany).

\section{Results}

\section{$16 S$ rRNA sequence analysis}

165 rRNA encoding DNA from Malonomonas rubra was amplified in vitro and directly sequenced. The sequence was deposited at the EBI data library under accession number 17712. A comparative database analysis revealed highest sequence similarity $(95.6 \%$; Table 1$)$ with Pelobacter acidigallici (SCHINK and PFENNIG, 1982). These two organisms together with Desulfuromusa species represent a monophyletic cluster sharing $94.6 \%$ and more $16 \mathrm{~S}$ rRNA similarity (Table 1). This cluster is part of one of the major phylogenetic groups of the delta subclass of the Proteobacteria comprising the genera Desulfuromonas, Desulfuromusa, Geobacter, Malonomonas, and Pelobacter (Figure 1).

\section{Cytochrome contents of cells and cell subfractions}

Cells of $M$. rubra contained cytochromes which stained colonies in deep-agar cultures orange-red (DEHNING and SCHINK, 1989). Redox-difference spectra of cell-free extracts exhibited absorption bands at 551,552 , and $419 \mathrm{~nm}$ wavelength as typical of a $c$-type cytochrome. After growth with malonate, $60-65 \%$ of this cytochrome was found in the cytoplasm, $20-22 \%$ in the periplasmic space, and $10-15 \%$ associated with the 
Table 1. Overall 165 rRNA sequence similarities of Malonomonas rubra, its closest relatives and the major phylogenetic groups of the delta subclass of the Proteobacteria. Mean values are given for phylogenetic groups (Desulfuromonas, Geobacter, Desulfobacter, Desulfobulbus, Syntrophobacter, Myxobacteria and Desulfovibrio). Abbreviations: Da, Desulfobacter; DI, Desulfobulvus; Do, Desulfuromonas; Du, Desulfuromusa; Dv, Desulfovibrio; G., Geobacter; M., Malonomonas; My, Myxobacteria; P., Pelobacter; Sb, Syntrophobacter; Su, Syntrophus; ', the group comprises Desulfuromonas acetexigens, "Desulfuromonas palmitatis", Pelobacter acetylenicus, P. carbinolicus and P. venetianus; ", the group comprises Geobacter metallireducens, G. sulfureducens, "G. hydrogenophilus", Pelobacter propionicus and "P. chapelleit"; ${ }^{3}$, the group comprises the genera Desulfobacter, Desulfobacterium, "Desulfobacula", "Desulfobotulus", Desulfacoccus, Desulfonema and Desulfosarcina; ${ }^{4}$, the group comprises the genera Desulfobulbus, Desulfofustis, "Desulforbopalus" and Desulfocapsa; ", the group comprises the genera Syntrophobacter, "Desulfoacinom" and "Desulforbabdus"; ", the group comprises the genera Angiococcus, Archangium, Cystobacter, Melitangium, Myxococcus and Stigmatella; ${ }^{7}$, the group comprises the genera Desulfovibrio, Desulfohalobium and Desulfomicrobium".

\begin{tabular}{|c|c|c|c|c|c|c|c|c|c|c|c|c|c|}
\hline \multirow[t]{2}{*}{ Organisms } & \multicolumn{13}{|c|}{ Overall 165 rRNA sequence similarity $(\%)$} \\
\hline & $\mathrm{Pa}$ & Dub & Duk & Dus & Doa & Do & $G$ & $\mathrm{Da}$ & DI & Sb & $\mathrm{Su}$ & My & $\mathrm{Dv}$ \\
\hline M. rubra & 95.6 & 95.0 & 94.6 & 94.8 & 92.2 & 91.9 & 87.6 & 84.0 & 83.8 & 84.0 & 85.1 & 81.8 & 82.1 \\
\hline P. acidigallici & & 94.6 & 94.8 & 94.8 & 92.2 & 92.2 & 88.7 & 83.9 & 84.2 & 84.3 & 85.3 & 82.4 & 82.6 \\
\hline Du. bakii & & & 98.8 & 98.3 & 90.7 & 91.8 & 87.3 & 83.5 & 83.5 & 83.5 & 84.1 & 81.7 & 82.2 \\
\hline Du. kysingii & & & & 98.3 & 90.7 & 92.0 & 87.4 & 83.5 & 83.5 & 83.7 & 84.3 & 81.8 & 82.4 \\
\hline Du. succinoxidans & & & & & 90.9 & 91.6 & 87.1 & 83.2 & 83.5 & 83.9 & 84.1 & 81.6 & 82.1 \\
\hline Do. acetoxidans & & & & & & 89.9 & 88.9 & 84.2 & 84.5 & 84.4 & 87.1 & ; 83.4 & 82.9 \\
\hline Desulfuromonas ${ }^{1}$ & & & & & & & 90.1 & 83.6 & 84.0 & 84.6 & 86.3 & 83.2 & 82.5 \\
\hline Geobacter ${ }^{2}$ & & & & & & & & 83.7 & 84.1 & 84.3 & 84.1 & 83.9 & 82.1 \\
\hline Desulfobacter ${ }^{3}$ & & & & & & & & & 83.0 & 82.4 & 85.2 & 80.3 & 81.2 \\
\hline Desulfobulbus ${ }^{4}$ & & & & & & & & & & 83.8 & 86.0 & 81.3 & 81.8 \\
\hline Syntrophobacter & & & & & & & & & & & 84.4 & 81.9 & 81.3 \\
\hline Syntrophus & & & & & & & & & & & & 83.0 & 82.1 \\
\hline Myxobacteria & & & & & & & & & & & & & 79.8 \\
\hline Desulfovibrio & & & & & & & & & & & & & \\
\hline
\end{tabular}

membrane fraction. Malic dehydrogenase as a tracer of cytoplasmic proteins was found to $99.5 \%$ in the cytoplasm, $0.4 \%$ in the periplasm, and less than $0.1 \%$ in the membrane fraction, indicating that the above distribution was not altered significantly by the fractionation procedure. The membrane-associated cytochrome $c$ could not be solubilized with $0.2 \mathrm{M} \mathrm{KCl}$ but was resolved from the membranes nearly quantitatively (>90\%) with $1 \%$ Triton $\mathrm{X}-100$.

\section{Purification of the cytochrome}

The cytochrome was most easily accessible at high concentration in the periplasmic fraction, and enrichment and isolation started from this fraction, therefore. Part of the contaminating proteins was bound to an anion exchanger DE 52 in $50 \mathrm{mM}$ Tris-HCl buffer, $\mathrm{pH}$ 7.0, which did no bind the cytochrome. A Mono $S$ cation exchanger equilibrated with $25 \mathrm{mM}$ sodium phosphate, $\mathrm{pH} 7.0$, bound $83 \%$ of the cytochrome which was eluted subsequently with a linear $\mathrm{NaCl}$ gradient at $0.27-0.30$ $\mathrm{M}$ concentration. Gel filtration on Sepharose 12 and hydrophobic interaction chromatography yielded a homogeneous cytochrome preparation which exhibited only one protein band after SDS polyacrylamide gel electrophoresis and silver staining. This band was also stained with high sensitivity by specific heme staining. The enrichment was 5.9 -fold, with a yield of $11.6 \%$.

Enrichment of the cytoplasmic cytochrome by separation on S-Sepharose and Superdex 75 led to a $c y$ - tochrome preparation with spectroscopic properties nearly identical to those of the periplasmic cytochrome preparation. The membrane fraction contained, beyond the c-type cytochrome, also a small fraction of a $b$-type cytochrome which could be identified by pyridine hemochrome extraction (absorption bands 556,540 and $410 \mathrm{~nm}$ ) but was not characterized further.

\section{Characterization of the periplasmic cytochrome $c$}

The molecular mass of the purified cytochrome $c$ was determined by gel filtration chromatography to be $13.7 \pm$ $0.3 \mathrm{kD}$, in comparison with standard proteins of 1.4-26.6 kD molecular mass.

Absorption spectra of the purified cytochrome $c$ in it oxidized and reduced form are shown in Fig. 2. The reduced cytochrome had absorption maxima at 551, 522, and $418 \mathrm{~nm}$, the oxidized form a maximum at $407 \mathrm{~nm}$. The specific absorption of the $\alpha$ band of the reduced form of the cytochrome at $551 \mathrm{~nm}$ wavelength was $32.6 \mathrm{mM}^{-1} \times \mathrm{cm}^{-1}$, calculated on the basis of the determined molecular mass. With the specific absorption coefficient of the purified cytochrome, it could be estimated that up to $12 \%$ of the total protein content of M. rubra cells was cytochrome protein.

Atomic absorption spectroscopy of the periplasmic cytochrome $c$ revealed four heme per molecule, as compared to commercially available monoheme cytochrome $c$ from horse heart (Sigma biochemicals). 


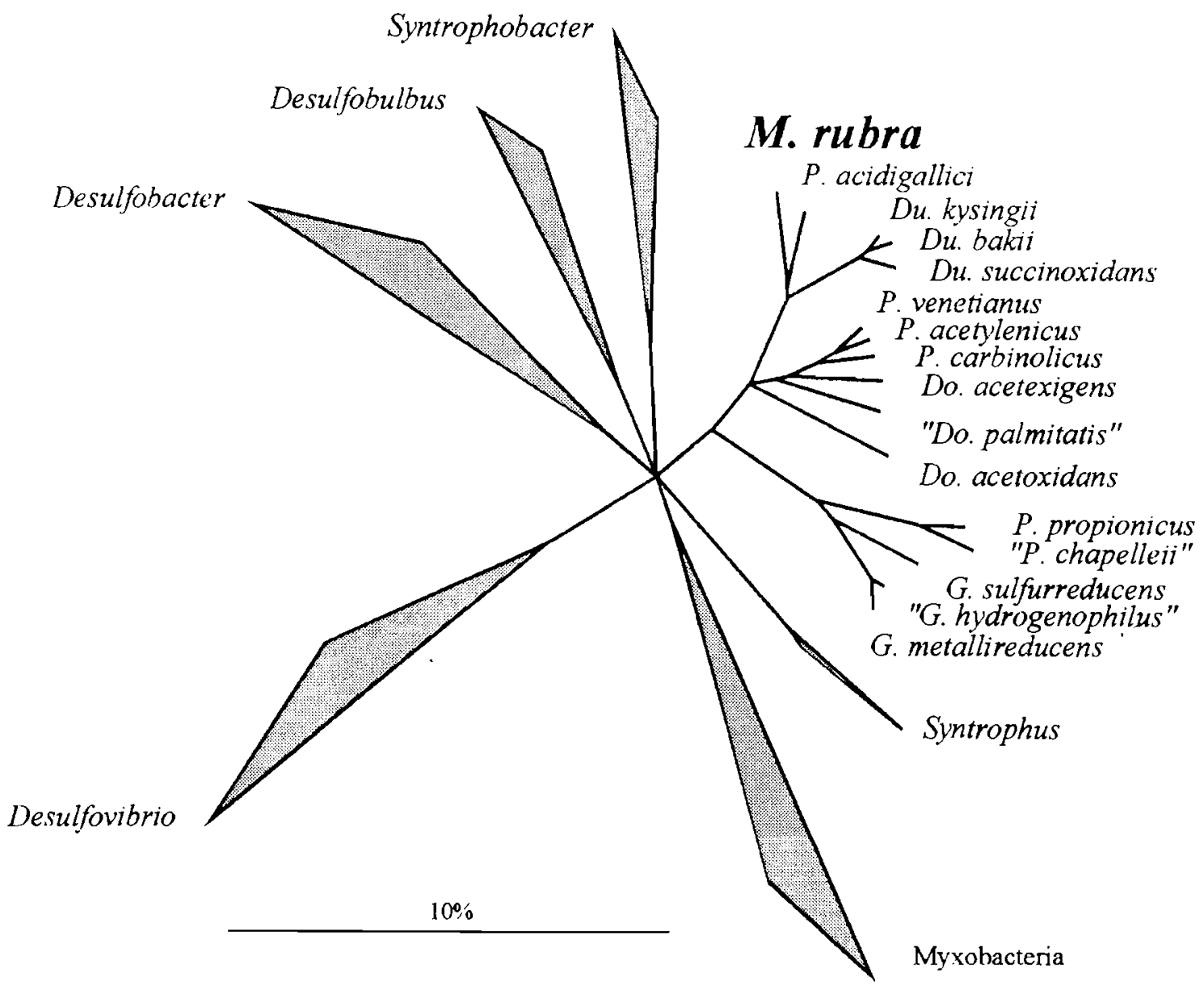

Fig. 1. $16 \mathrm{~S}$ rRNA based tree reflecting the relationships of Malonomonas rubra, its closet relatives and the major phylogenetic groups of the delta-subclass of the Proteobacteria. The topology of the tree is based on the results of a distance matrix analysis. Only sequence positions which share identical residues among $50 \%$ of all available (at least almost) complete $16 \mathrm{~S} \mathrm{rRNA}$ sequences from the delta subclass proteobacteria were included for tree construction. Multifurcations indicate that a common relative branching order was not supported by the results obtained performing different treeing methods. Phylogenetic groups are indicated by triangles. The bar indicates $10 \%$ estimated sequence divergence. Abbreviations are as specified in the legend to Table 1.

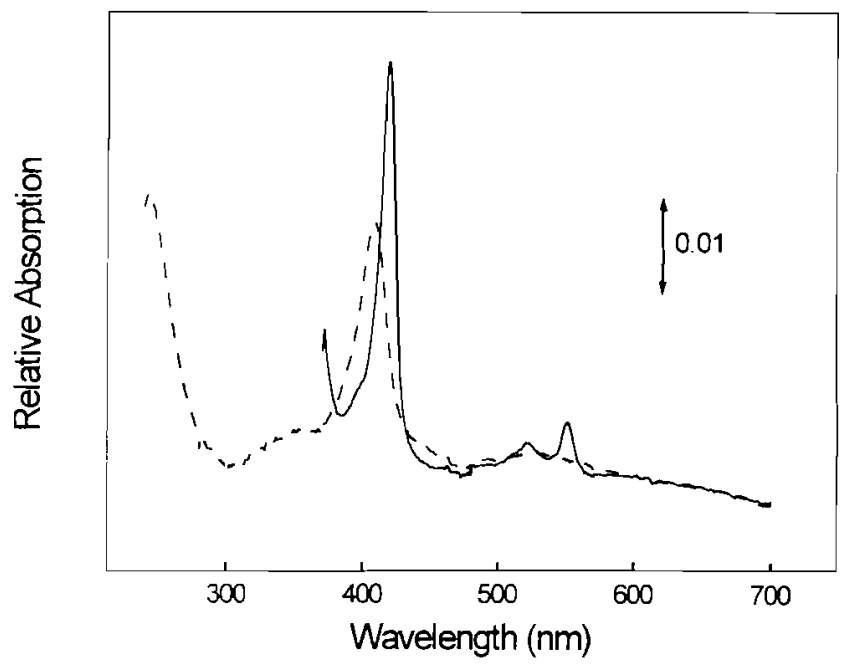

Fig. 2. Dithionite reduced (solid line) and $\mathrm{H}_{2} \mathrm{O}_{2}$ oxidized (dashed line) spectra of cytochrome $c$ from the periplasm of Malonomonas rubra.

\section{Electron donor and acceptors}

The periplasmic cytochrome $c$ was reduced by dithionite, Ti(III) NTA, $\mathrm{H}_{2} \mathrm{~S}$, or dithioerythritol, but not by cysteine or ascorbate. It was oxidized quickly by $\mathrm{O}_{2}$. A redox titration with indigodisulfonic acid, flavin mononucleotide, flavin adenin dinucleotide, and benzyl viologen resolved three redoxpotentials of the cytochrome. The identified redox potentials of individual heme groups were $-0.120 \mathrm{~V},-0.220 \mathrm{~V}$ and $-0.370 \mathrm{~V}$ (each with a standard error of $\pm 0.020 \mathrm{~V}$ ).

\section{Physiological experiments}

The cytochrome $c$ in intact cells was reduced upon addition of malonate or acetate, and oxidized by oxygen. Under anoxic or microoxic conditions $(\leq 5 \%$ air saturation), malonate was fermented to acetate without substantial increase in cell density. The cytochrome content of intact cells was identical after growth with malonate 
or fumarate; it did not change either upon exposure to air oxygen. Elemental sulfur, polysulfide, or ferric iron hydroxide [ferrihydrite, $\mathrm{Fe}(\mathrm{OH})_{3}$ ] was not reduced with malonate or fumarate as electron donor. No oxygen-dependent oxidation o facetate could be observed, not even in dense cell suspensions.

\section{Discussion}

\section{Phylogenetic position of Malonomonas rubra}

The status of Malonomonas rubra as a species representing its own genus is supported by substantial $16 \mathrm{~S}$ rRNA sequence difference $(4.4 \%)$ to its so far closest relative Pelobacter acidigallici (Table 1, Figure 1). This is the type species of the genus Pelobacter (SCHINK and PFENNIG, 1982). These two genera, together with Desulfuromonas and Geobacter, are members of one of the major phylogenetic groups of the delta subclass of the Proteobacteria. The group is monophyletic and significantly separated from he other delta proteobacteria as supported by the results of various analyses using differing datasets and applying alternative treeing methods, as shown in the tree of Figure 1. However, within this group only Desulfuromusa and Geobacter are monophyletic genera, whereas Desulfuromonas and especially Pelobacter are phylogenetically heterogenous. Given that Pelobacter acidigallici is the type species of its genus and Malonomonas rubra its closest relative, a taxonomic reevaluation of the genus Pelobacter may appear necessary in the future.

\section{Comparison of the periplasmic $c$-type cytochrome with other known cytochromes}

The redox difference spectrum of the cytochrome $c$ purified from the periplasmic fraction of $M$. rubra is typical of the class III (multiheme) cytochromes found in sulfate- and sulfur-reducing bacteria: there was to $695 \mathrm{~nm}$ absorption in the oxidized form and a shoulder on the short wavelength side of the Soret band (PETTIGREW and MOORE, 1987). Compared to known tri- and tetra-heme class III cytochromes (PETTIGREW and MOORE, 1987) from sulfate- and sulfur-reducing bacteria, the cytochrome $c$ described here does not differ substantially by its molecular mass and its midpoint redox potential. Cytochromes of Desulfovibrio vulgaris strain Miyazaki (SOKOL et al., 1980), D. vulgaris strain Hildenborough (DERVARTANIAN et al., 1978; BrusCHI et al., 1984), D. salexigens strain Benghazi (DruCKER et al., 1970), D. gigas (XAVIER et al., 1979), D. desulfuricans strain Norway (BrusCHI et al., 1977; BrusCHI, 1981), and Shewanella putrefaciens (MORRIS et al., 1994) have molecular masses of $13 \mathrm{kD}$ or higher, and standard redox potentials below $-0.2 \mathrm{~V}$. Desulfobulbus elongatus has a cytochrome of a standard redox potential of $-0.165 \mathrm{~V}$ and a molecular mass of $13.7 \mathrm{kD}$ (SAMAIN et al., 1986). All cytochromes mentioned have nearly identical absorption maxima ( $\pm 2 \mathrm{~nm}$ wavelength) both in their reduced and oxidized forms. The cytochrome $c$ from Desul- furomonas acetoxidans has standard redox potentials of the three hemes at $-0.102,-0.177$, and $-0.177 \mathrm{~V}$ (according to FIECHTNER and KASSNER, 1979) or -0.140 , -0.210 and $0.240 \mathrm{~V}$ (according to BRUSCHI et al., 1984). The specific absorption coefficient at the $\alpha$ absorption band (at $551 \mathrm{~nm}$ wavelength) of the reduced $M$. rubra cytochrome was $32.6 \mathrm{mM}^{-1} \times \mathrm{cm}^{-1}$, similar to that of the three-heme cytochrome $c$ of $D$. acetoxidans $\left(30.8 \mathrm{mM}^{-1}\right.$ $\times \mathrm{cm}^{-1}$; ProBST et al., 1977).

\section{Possible physiological function of the periplasmic cytochrome $c$}

The cytochrome described here was oxidized in intact cells by oxygen, and reduced by their growth substrates malonate and fumarate, but also by their fermentation product acetate. There is no indication of an involvement of this $c$-type cytochrome in reduction of fumarate to succinate (DEHNING and SCHINK, 1989), rather, the $b$ type cytochrome present in the cytoplasmic membrane is more prone to a function in such an electron transport. The observed reduction of the cytochrome in intact cells by substrates such as malonate or acetate is probably enabled by oxidation of acetyl CoA through the tricarboxylic acid cycle. M. rubra is known to contain all reactions of this cycle which operates either in acetyl CoA oxidation for cell carbon synthesis from acetyl residues during growth with malonate or in a non-cyclic manner during growth with fumarate (DEHNING and SCHINK, 1989). Electrons for reduction of the cytochrome with its comparably low midpoint redox potential $(-0.210 \mathrm{~V})$ are most likely to be provided in the isocitrate dehydrogenase $(-0.350 \mathrm{~V}, \mathrm{NAD}$-dependent) and the 2-oxoglutarate ferredoxin oxidoreductase $(-0.370 \mathrm{~V}$; benzylviologen-dependent) reaction. Nonetheless, since no external electron acceptors are reduced in acetate oxidation, this cytochrome appears not to fulfil a visible function in growth during fermantation of malate or fumarate.

The biochemistry of malonate decarboxylation has been elucidated. Malonate binds to the enzyme protein to form an S-malonyl enzyme complex, in exchange for a bound acetyl residue, and is decarboxylated in the S-malonyl form by carboxyl transfer to a biotin carrier (HILBI et al., 1992). Thus, the $c$-type cytochrome appears not to be involved in the decarboxylation reaction either; it had been hypothesized earlier that it could act as a radical generator if the free malonate molecule was decarboxylated by a radicalic mechanism.

The obvious phylogenetic relationship of $M$. rubra to sulfur-reducing bacteria suggested that the cytochrome present, similar to those found in sulfur reducers, might act in electron transfer to sulfur as external electron acceptor. Also ferric iron-reducing bacteria are phyletically related to the sulfur reducers on the basis of $16 \mathrm{~S}$ rRNA sequence similarities (CACCAVo et al., 1994), and also these bacteria contain cytochromes, either associated with the cytoplasmic membrane and the periplasmic space (MYERS and MYERS, 1992) or in the periplasm and even outside the cells (SEELIGER et al., 1998). We therefore checked again thoroughly for possible reduction of 
sulfur or ferric iron by M. rubra but could not find any indication of such activities.

We conclude that the c-type cytochrome of $M$. rubra does not fulfill an essential physiological function in the energy metabolism of this bacterium but may be a remnant from sulfur- or ferric iron-reducting ancestors to which it appears to be related on the basis of $16 \mathrm{~S} r \mathrm{RNA}$ sequence similarity data.

\section{Acknowledgments}

The technical assistance of INGRID POMPER is highly acknowledged. The authors also appreciate support through grants of the Deutsche Forschungsgemeinschaft, Bonn-Bad Godesberg.

\section{References}

BRADFORD, M. M.: A rapid and sensitive method for the quantitation of microgram quantities of protein utilizing the principle of protein-dye binding. Anal. Biochem. 72, 248-254 (1976).

BRUSCHI, M.: The primary structure of the tetraheme cytochrome $c_{3}$ from Desulfocibrio desulfuricans (strain Norway 4). Description of a new class of low-potential cytochromes i. Biochim. Biophys. Acta 671, 219-224 (1981).

Bruschi, M., Hatchikian, C. E., Golovieva, L. A., Le Gall, J.: Purification and characterisation of cytochrome $c_{3}$, ferredoxin, and rubredoxin isolated from Desulfovibrio desulfuricans (Norway). J. Bacteriol. 129, 30-38 (1977).

Bruschi, M., Loutfi, M., Blavco, P., Haladjlan, J.: Correlation studies between structural and redox properties of cytochromes $c_{3}$. Biochem. Biophys. Res. Comm. 120, 384-389 (1984).

Caccavo, F., Jr., Lonergay, D. J., Lovley, D. R., Davis, M., SOTZ, J. F., MCINERnEY, M. J.: Geobacter sulfurreducens sp. nov., a hydrogen- and acetate-oxidizing dissimilatory metalreducing microorganism. Appl. Environ. Microbiol. 60, $3752-3759(1994)$.

DeHNING, I., SCHINK, B.: Malonomonas rubra gen. nov. sp. nov. a microaerotolerant anaerobic bacterium growing by decarboxylation of malonate. Arch. Microbiol. 151, 427-433 (1989).

Dervartanian, D. V., Xavier, A. V., Le Gall, J.: EPR determination of the oxidation-reduction potentials of the hemes in cytochrome $c_{3}$ from Desulfovibrio vulgaris. Biochimie 60, 321-325 (1978).

Drucker, H., Trousil, E. B., Campbell, L. L.: Purification and properties of cytochrome $c_{3}$, of Desulfovibrio salexigens. Biochem. 9, 3395-3400 (1970).

FIECHTNER, M. D., KASSNER, J. R.: The redox properties and heme environment of cytochrome c-551.5 from Desulfuromonas acetoxidans. Biochim. Biophys. Acta 579, 269-278 (1979).

GOODHEW, C. F., Brown, K. R., PetTigrew, G. W.: Haem staining in gels, a useful tool in the study of bacterial $c$-type cytochromes. Biochim. Biophys. Acta 852, 288-294 (1986).

Hilbi, H., Dehning, I., Schink, B., Dimroth, P.: Malonate decarboxylase of Malonomonas nibra, a novel type of biotincontaining acetyl enzyme. Eur. J. Biochem. 207, 117-123 (1992).

LAEMMLI, U. K.: Cleavage of structural proteins during the assembly of the head of bacteriophage T4. Nature 227, 680-685 (1970).

LuDWIG, W.: Sequence databases. In: Molecular microbial ecology manual. (AKKermans, A. D. L., ed.) 3.3.5, 1-22 (1995).
LUDWIG, W., STRLNK, O.: ARB: a software environment for sequence data. http://www.mikro.biologie.tu-muenchen.de/ pub/ARB/documentation/arb.ps (1996).

Morris, C. J., Black, A. C., Pealing, S. L., Manson, F. D. C., Chapman, S. K., Reid, G. A., Gibson, D. M., Ward, F. B.: Purification and properties of a novel cytochrome: flavocytochrome $\mathrm{c}$ from Chewanella putrefaciens. Biochem. J. 302, 587-593 (1994).

MyERS, C. R., MYERS, J. M.: Localization of cytochromes to the outer membranes of anaerobically grown Shewanelly putrefaciens MR-1. J. Bacteriol. 174, 3429-3438 (1992).

Pettigrew, G. W., Moore, G. R.: Cytochrome c-biological aspects. Springer New York (1987).

Probst, I., Bruschi, M., Pfennig, N., Le Gall, J.: Cytochrome c-551.5 from Desulforomonas acetoxidans. Biochim. Biophys. Acta 460, 58-64 (1977).

SaMain, E., Albagiac, G., Le Gall, J.: Redox studies of the tetraheme cytochrome $c_{3}$ isolated form the propionate-oxidizing, sulfate-reducing bacterium Desulfobulbus elongatus. FEBS Lett. 204, 247-250 (1986).

Schink, B., Pfenvig, N.: Fermentation o trihydroxybenzenes by Pelobacter acidigallici gen. nov. sp. nov, a new strictly anaerobic non-sporeforming bacterium. Arch. Microbiol. 133, 195-201 (1982).

Seeliger, S., Cord-Ruwisch, R., Schink, B.: A periplasmic and extracellular $c$-type cytochrome of Geobacter sulfurreducens acts as ferric iron reductase and as electron carrier to other acceptors and to partner bacteria. J. Bacteriol. (submitted).

SOKOL, W. F., Evans, D. H., NiKi, K., YAGI, T.: Reversible voltammetric response for a molecule containing four nonequivalent redox sites with application to cytochrome $c_{3}$ of Desulfovibrio vulgaris, strain Miyazaki. I. Electroanal. Chem. 108, 107-115 (1980).

Springer, N., Ludwig, W., Drozanski, V., Amann, R. SCHLEIFER, K. H.: The phylogenetic status of Sarcobium lytictum, an obligate intracellular parasite of small amoebae. FEMS Microbiol. Lett. 96, 199-202 (1992).

Stims, A. J. M., Kremer, D. R., Nicolay, K., Weenk, G. H., HANSEN, T. A.: Pathway of propionate formation in Desulfobulbus propionicus. Arch. Microbiol. 137, 329-337 (1984).

ThOMas, P. E., Ryan, D., LEvin, W.: An improved staining procedure for the detection of the peroxidase activity of cytochrome $P-450$ on sodium dodecyl sulfate polyacrylamide gels. Anal. Biochem. 75, 168-176 (1976).

TSCHECH, A., PFENNig, N.: Growth yield increase linked to caffeate reduction in Acetobacterium woodii. Arch. Microbiol. 137, 163-167 (1984).

WESTON, J. A., KNOWLES, C. J.: A soluble CO-binding c-type cytochrome from the marine bacterium Beneckea natriegens. Biochim. Biophys. Acta 305, 11-19 (1973).

Widdel, F., Pfennig, N.: Studies on dissimilatory sulfate-reducing bacteria that decompose fatty acids. I. Isolation of a new sulfate-reducer enriched with acetate from saline environments. Description of Desulfobacter postgatei gen. nov. sp. nov. Arch. Microbiol. 129, 395-400 (1981).

Widdel, F., Kohring, G. W., MAYER, F.: Studies on dissimilatory sulfate-reducing bacteria that decompose fatty acids. III. Characterization of the filamentous gliding Desulfonema limicola gen. nov. sp. nov., and Desulfonema magnum sp. nov., Arch. Microbiol. 134, 286-294 (1983).

Xavier, A. V., Moura, J. J. G., Le Gall, J., Dervartaniax, D. V.: Oxidation-reduction potentials of the hems in cytochrome $c_{3}$ from Desulfovibrio gigas in the presence and absence of ferredoxin by EPR spectroscopy. Biochimie 61, 689-695 (1979).

Corresponding author: BERNHARD SCHINK, Fakultät für Biologie, Universität Konstanz, Postfach 5560, D - 78434 Konstanz, Germany 